\title{
Socio-literary Study of Robert Browning and Darwesh Durrani’s Dramatic Monologues: A Comparative Literary Approach
}

* Raham Dil Khan, Undergraduate Student

** Dr. Khan Sardaraz, Director ORIC

\begin{abstract}
Previous literature is laden with research on Browning's dramatic monologues from various perspectives. This paper will compare Browning's dramatic monologues with Derwesh Durrani's poetry from socio-literary perspective. Literary theories of analogy and variation will be used to find out similarities and differences in their poetry. Two poems from each poet have been selected for analysis through close reading technique on the model of theories of variation and analogy. Stratified sampling technique was used for taking the representative sample from the data. The findings reveals that Darwesh's poetry exhibits most of the dramatic features of Browning's dramatic monologues, but his poetry is more poetic, while Browning's poetry is more dramatic; Browning invigorates the past, Darwesh recreates the present. In addition, Browning's poems deals with domestic issues like gender violence, love and marriage, Darwesh's poetry deals with social issues and patriotism, and contrary to Browning, he stands for women's rights and sensibilities. This paper suggests further studies purely from socio-cultural perspective of Darwesh's dramatic monologues, which will contribute to the existing literature on dramatic monologues.
\end{abstract}

Key words: Dramatic monologue, lyrics, analogy, variation, gender.

\section{Introduction}

Browning and Tennyson have often been credited with writing poems, which come within the genre of 'dramatic monologue', but they never used this term to refer to their poetical works. Browning, famous for writing dramatic monologues, did not use the term dramatic monologue for his works, but he often used such terms for his works that bore the attributes of dramatic art, such as 'dramatic lyrics' 'Dramatic Romances and Lyrics' 'Dramatis personae'. The use of such terms with reference to his poems reflects that Browning was aware of the fact that his poems are having dramatic features (Culler, 1975). This term was

\footnotetext{
* Department of English and Applied Linguistics, University of Science \& Technology, Bannu Email: rdk.wazir@gmail.com

** University of Science \& Technology, Bannu

Email: sardarazsorani@gmail.com
} 
used for the first time by George W. Thornbury in 1857 for a collection of his poems in his Songs of the Cavaliers and Roundheads, Jacobite Ballads which were saturated with characteristics that were present in Browning's poetry (Culler, 1975). It was after then that the critics started to study the unique characteristics that were widely exercised by Browning in his poetry.

Dramatic monologue is defined as "a soul in action through the speech one character in a dramatic situation" (Holman \& Harmon, 1992: 158), yet the conception of the term 'Dramatic Monologue' has been debated in the literature, and has attained different definitions from different critics. Sessions (1947) has given a very detailed definition of the term, and holds that if a work of prose or poetry has the seven features i.e. a speaker, listener, event, action, the action might be dramatic, interaction between speaker and listener and character portrayal, it may be termed as dramatic monologue. Sessions (1947) holds that Browning's poem, My Last Duchess has all these seven features and can be termed as a typical dramatic monologue. In My Last Duchess, the duke is speaker, the diplomat is listener, his preparation for next marriage on death of duchess constitutes the dramatic action, character revelation through his speech about the last duchess and the action unfolding through his interaction with the diplomat throughout the poem talking about himself and about his late duchess. However, Sessions has mainly focused on the taxonomic features of dramatic monologue which tends to be reductive, and such a definition cannot comprehensively encompass the whole of the genre (Roche-Jacques, 2013: 2-3). Sinfeild (1977: 21-30) has given a very broad definition of dramatic monologue, as every poem is a dramatic monologue in which speaker is other than the poet himself. The speaker expresses his own views rather than the poet's views, and the reader is placed to assume it so knowing that the speaker is a dramatic creation. The use of the speaker 'I' makes it dialogic rather than monologic.

Byron (2003) holds that dramatic monologue is a genre which may have different forms. She adds to the existing debate on dramatic monologue by dislocating a specific listener from the poet's world of fiction. According to her, a dramatic monologue may lack a listener/auditor and then the place of listener/auditor is reserved for the readers. Byron supports her argument with reference to poems of Carol Ann Duffy, Simon Armitage and others, which are directly addressing the silent listeners/auditors but lack them at some point and then the place of auditor is reserved for the readers (Byron, 2003: 143). In Curry' views (1908: 7-127), dramatic monologue have three main features the speaker, the listener and they are put in an event, and the poem should have spatial and temporal orientation. 
The above discussions show the debate on the definition of the dramatic monologue. The vagueness is because of the broad and vague nature of the word 'dramatic'. However, the broad nature of what is dramatic can help in appreciating a large number of poetic works as dramatic monologues, which add to the variety of the genre. Sinfield regards dramatic monologue as a kind of speech in fiction (Sinfield, 1977: 21).

Browning (1812-1889) became the well-known figure/writer of his contemporary era because of his mastery in dramatic verse. In his dramatic monologues, he is mainly concerned with the progress and development of inner self (Sharp, 1897: 37). He has been examined extensively in previous literature from different perspectives e.g. gender perspective (Ingersoll, 1991), (Maenhout, 2007) and (Haigwood, 1986), literary and dramatic perspective (Sessions, 1947), (Wenger, 1941), (Garratt, 1973) and (Culler, 1975), domestic violence perspective (Culler 1975; Gregory, 2000) and (Salunke, 2014), sympathy and judgement (Scheinberg, 1997), and his necro-poetics (Fox, 2011). Comparative studies have also been conducted on him and other poets, comparison of John Donne's philosophy and artistic theory with Browning (Duncan, 1953), comparison of Morrison's poem with Browning's dramatic monologues (Hodgson, 1992), similarity of musicality between Tennyson and Browning (Plamondon, 2002), similarity between John Betjeman's "Bristol and Clifton" and Browning's dramatic monologues with particular reference to My Last Duchess (Gardner, 2006) and poetic similarities and differences between Tennyson and Robert Browning (Prakash, 2017). However, scarce literature is available on investigation of dramatic monologues in South Asian literature and Browning's comparison with them.

Darwesh Durrani is one of the contemporary Pashto poets, who wrote Pashto poetry extensively on various topics. However, previous research on him is minimal. Most of the studies have investigated him in literary and social perspective, such as his attitude towards war on terror (Khalil, 2012), stylistic techniques in his Ghazals (Iqbal, 2008), rhyme schemes and imagery (Ghazanfar, 2014), subjects of his poetry (Bajawrhi, 2007) and poetic attributes and criticism on society (Hamdard, 2015). Darwesh often laments over the social issues, tribal discord, ignorance and moral and political decline of Pashtun community. Major portion of his poetry reflects social illness of his community and urges them to remove the shortcomings to get a respectable place in the comity of the nations (Bajawrhi, 2007; Sabir, 1978). Social decadence, moral decline and the consistent war and terrorism have found large portion in his poetry, and therefore, he is called as the poet of peace and the Physician of Pashtun community (Bajawrhi, 2007). Zahir (2011) calls his poetry as the historical document of upcoming modern changes in enlightened thinking to awaken the community. 
Perhaps, he was more concerned with socio-political issues, and therefore, he might have opted for dramatic poetry to make his poetry more objective, which can have more effect on the people. However, perhaps no study has so far been carried out on dramatic quality of his poetry. This paper will focus on the dramatic quality in socio-literary perspective of Darwesh Durrani's poetry by comparing him with Robert Browning's dramatic monologues.

No doubt, comparative studies have been conducted on English and Pashto literature, such as (Bacha, 2010; Ehsan, 2016; Muhammad, 2016), yet it is very scarce, and has been carried on few poets. No work has yet been carried out to investigate the dramatic elements or techniques in Pashto poetry. This study will be instrumental in recognition of dramatic in Pashto poetry, and will pave the way for further research in comparative literature on English and Pashto poets. This paper will specifically focus on analysis of dramatic monologue in Pashto poetry of Darwesh and compare it Browning to find out their similarities and differences on the model of theories of analogy and variation.

\section{Methodology}

Data has been taken from Robert Browning's dramatic monologues and Darwesh's poetic work (ستوري پِه لمن كبني) - "Stori puh Lamun Ke". This paper opted for two poems from each poet on the basis of their significance in literature i.e. "Andrea de Sarto and My Last Duchess" from Browning and (آخري سوغات) "Akhri sawgháat-"the last gift” and (ناوي) "navethe bride" from Darwesh. Close reading technique was used to search for similarities and differences in theese poems. Structured sampling method was used to take representative population from each poem for analysis. The analysis of the data was carried out with the help of rheory of analogy and variation theory.

Theory of analogy seeks the similarities or commonalities present in two different literatures or two different cultures despite variations in their language, culture and religion (Wellek \& Warren, 1956; Remak, 1971). The main objective/aspect of the theory "study of analogy" is to find out similarities between two situations. Variation theory focuses on the existing differences between literature of different languages and cultures (Cao \& Shi, 2011). Variation theory focuses on the differences that exist between different civilizations. This theory seeks to find out the variation that are present between two cultures and literature that makes them unique or give them identity. These variations can either be at linguistic level, or in image of a nation, or in literary text and/or in culture. Cao's theory insists on the variations and heterogeneity existing between two cultures, literatures and languages. This paper will compare the two poets of different cultures on these two theories to investigate the literary attributes and social approach of the two poets. 


\section{Data Analysis}

Through the theory of analogy and Variation theory, analysis have been carried out, and Robert Browning's poems have been used as a framework to analyze Darwesh poems. The analysis of the data by combining the two theories is detailed as below.

\section{Analysis of Browning's Poems}

The paper has analyzed the theme and setting, imagery, diction, verse form, and other dramatic elements in the poem.

\section{Theme and Setting}

Both selected poems of Browning are set in Italy. In Andrea del Sarto, the speaker Andrea and his wife Lucrezia are present in a painting room. Andrea is painting for her, and the room is full of paintings but Lucrezia does not care for his paintings and smears it carelessly with her dress. The setting of this poem focuses on past. The theme of the poem Andrea del Sarto is the success and failure in life and art of Andrea. He is a master of art but his personal life is not successful, and his wife does not show love for him. The poem only depicts a single individual and his fate at the hands of his beloved.

My Last Duchess is based on events and incidents in the life of Duke of Ferrara in Italy, whose first wife died after three years of their marriage. Following her death, the duke negotiates through an envoy for the second marriage in a room. The Duke addresses the envoy, and talks about his late wife painting. Browning has used the theme of power and gender in My Last Duchess. The duke thinks of himself to be a respected person because of his nine hundred years old name, and he felt that the late duchess did not show such respect for him that he deserved. He considers her as a machine and not a human who can have any fault.

\section{Imagery}

The analysis reveals that browning has made use of figurative language to represent objects, actions, and ideas, which adds to the aesthetic effect of his poetry. Browning makes use of concrete images to make the context more scenic in his poetry.

1. "this evening more than usual, and it seems"

2. "how could you prick those perfect ears"

"Even to put the pearl there! Oh, so sweet" (Andrea del Sarto)

3. "That's my last Duchess painted on the wall,"

4. "..., Notice Neptune, though"

"Taming a sea-horse, thought a rarity"

"Which Claus of Innsbruck cast in bronze for me!" (My Last Duchess) 
The demonstrative pronoun "this" on combination with the temporal noun "evening" gives a scenic image of the event at (1). In (2), the act of pricking ears, even for wearing the pearl gives the poem an aesthetic touch. The lines at (3) and (4) present concrete images of paintings. The poet has also used metaphors to explain various states, which adds beauty to his poems, as is the case with the following lines.

5. "And I'm the weak-eyed bat..."

6. "my serpentining beauty, rounds and round!" (Andrea del Sarto)

In (5), Andrea compares himself with weak eyed bat, and in (6), the metaphor becomes ironic where the speaker calls his beloved as "serpentining beauty" to show the soft and slim body containing poison like cute serpent in its fangs. No metaphor is used in My Last Duchess, and the analysis found only one simile, where the Duke finds his wife alive in the painted picture.

7. "That's my last Duchess painted on the wall" "Looking as if she were alive." (My Last Duchess)

\section{Language and Verse}

The language that is used in both poems is simple and in conversational form, using direct speech with use of pronouns, and often employs negative and interrogative sentences.

8. "But do not let us quarrel anymore," "No, my Lucrezia; bear with me for once:"

9. "Sit down and all shall happen as you wish." "You turn your face, but does it bring your heart?"

10. "Speak as they please, what the mountain care?"

11. "Do not boast, perhaps: yourself are judge," (Andrea del Sarto)

12. "That's my last Duchess painted on the wall,"

13. "Will't please you sit and look at her? I said"

14. "The curtains I have drawn for you, but I)"

15. "Will't please you rise? We'll meet"

16. "She had /A heart--how shall I say?" ---(My Last Duchess)

The use of first and second person pronouns make his poetry more colloquial as is the case with my Lucrezia', in (8) "you wish", "you turn your face” and "your heart" in (9), "my last duchess" in (12), "I said" in (13), "I have drawn for you" in (14) and "We'll meet" in (15). Negative sense is used in (8) and (11), while lines at (9), (11), (13), (15) and (16) are in interrogative sense. Andrea del Sarto is composed in blank verse which does not rhyme, but has a regular rhythm and are in iambic pentameter. The verse form of My Last Duchess is 
heroic couplets, with regular rhyme scheme in every couplet. Heroic couplets are mostly used in epic poetry.

\section{Dramatic Elements}

Each of the poems of Browning has a speaker, a listener, an event/occasion, an action/conflict, dramatic action, interplay between speaker and listener and revelation of the characters (Sessions, 1947). Consider the following lines.

17. "But do not let us quarrel anymore," "No, my Lucrezia; bear with me for once:" "Sit down and all shall happen as you wish." "You turn your face, but does it bring your heart?"

18. "And look at half-hour forth on Fiesole" "Both of one mind as married people use". (Andrea del Sarto)

19. "That's my last duchess painted on the wall" "Looking as if she were alive...."

20. "will't please you sit and look at her? I said"

21. "How such a glance came there; so not the first" "Are you to turn and ask thus. Sir, 't was not...". (My Last Duchess)

In (17), the speaker Andrea is addressing the listener Lucrezia, entreating her to be with him. The speaker reveals himself as Lucrezia's husband at (16). Both (17) and (18) reveals a close interaction between the speaker and the listener, which revolves round Andrea's attempts to win the love of Lucrezia. The dramatic conflict in Andrea del Sarto is expressed in (17), which involves the external conflict between Andrea and Lucrezia on one hand, while internal conflict within the mind of Andrea regarding the worth of his art on the other, as expressed below.

22. "My works are nearer heaven, but I sit here".

The focal event or action in My Last Duchess is the marriage of the duke after the death of the duchess. The internal conflict is that the duke is always thinking about his late duchess and does not allow dust particle to durst the duchess' painting. He is now confused that was he really in love with her or not? The action of duke planning for next marriage is also dramatic. He is discussing plans for his next marriage with the envoy.

Revelation of character is one of key feature of dramatic monologue. The speaker reveals himself as well as others through his speech, as is the case with the following lines. 
23. "I can do with my pencil what can I know," "What I see, what at bottom of my heart"

24. "But do not let us quarrel anymore" "No my Lucrezia; bear with me for once"

25. "Treat his own subject after his own way" "Fix his own time, accept too his own price "And shut the money into this small hand,"

26. "Who strive---you don't know how the others strive" "To paint a little thing like that you smeared"

"Carelessly passing with your robes afloat"

27. "My face, my moon, my everybody moon" You smile? Why, there's my picture readymade"

28. “... why do I need you?"

"What wife had Rafael, or has Angolo!". (Andrea del Sarto)

29. "That's my last duchess painted on the," "Looking as if she were alive. I call"

30. "...Fra Pandolf hands" "Worked busily a day, and there she stands."

31. "But to myself they turned (since none puts by" "The curtain I have drawn for you, but I)" "And seemed as they would ask me, if they durst"

32. "...Oh sir, she smiled, no doubt,"

"Whene'er I passed her; but who passed without"

"Much the smile? This grew; I gave commands;". (My Last Duchess)

The speaker and listener are constantly revealed in the above lines, showing Andrea as an artist who can paint anything or idea, but if Lucrezia had been in love with him, as is the case with the above examples from (23) to (28). Lucrezia is revealed as unfaithful and cruel, who neither cares for him nor for his art as is evident "you smeared" at (26) and "my everybody's moon" at (27). Similarly, the duke is revealed through his speech as a domineering man as is evident from "they would ask me, if they durst" at (31) and "I gave commands" at (32). Thus, the speakers constantly reveal characters through his speech.

Browning main focus in his dramatic monologues, as evident from Andrea del Sarto and My Last Duchess is the love and marriage, gender and gender violence in society. Andrea del Sarto reveals the unrequited love of a man and the unfaithfulness of his wife, while My Last Duchess revolves round the violence committed by the duke against the duchess, but there is a silent but more powerful resistance from female desire which can withstand the overt power of man, as is evident from the portrait and its description by the duke. Thus, the main concern of Browning is the gender to gender relations, gender violence 
and gender power in domestic life of Victorian age in these two poems. In other words, the main concern of Browning in his poems is the social relationship in the Victorian age.

\section{Analysis of Darwesh's Poems}

Darwesh poems (ناوي) “Nave”-“The Bride' and (آخري سوغات) “Akhri Sawghat”- 'The Last gift' are analyzed below.

\section{Setting and Theme}

The text of Darwesh's poems do not explain the setting of the poems, however, through implicature, it is revealed that the poems are set in Pashtun society. The poem 'Nave' is composed on the custom of giving one's own daughter to the family of the murdered in return for avoiding revenge from the family of deceased. Thus, the theme of the poem is a social practice which is in vogue in Pashtun society since long. The bride addresses her father, and gives a baffling psychological picture of herself in her new home, being surrounded by people who have no love for her, but rather she is despised as the daughter of a murderer. She complains to her father for being cruel to her in giving her to his enemy in return for his life. The 'helplessness of women' in Pashtun society is revealed in the poem. He has raised a social issue in his poem Nave for the purpose of educating the public against this custom through sentimental speech of the girl.

In 'Akhri Sawghat', a girl brings back her late brother in her imagination, who had promised her to bring her the gift in the form of a young boy (fiancée) like a prince who will take care of her forever. Her brother went to the battle where he fought with bravery and got martyred, and his comrades brought his gun to her stained with his blood. She addresses her brother in sentimental way that the last best gift, she received from her brother, was his gun stained with blood. The theme of the poem is the continuous war in Pashtun speaking areas, where the yearnings of young girls and mothers are assassinated, and their sole hope for survival in this war-stricken area are lost. Hatred against the war and quest for peace are the prominent themes in this poem.

\section{Imagery}

Darwesh makes extensive use of figurative language in his sentimental lyrics. The analysis reveals that he makes use of metaphors and similes to make his message more instrumental in its effects. Consider the following lines.

Images in poem Nave

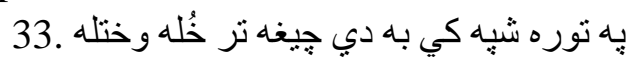

Pah turah shpa ke ba de chagha tar khwulay wukhatala

You used to cry in the dark night 
له سرو زخمونو سره مرك ؤ بِه غت كام دريسي .3aha

La sro zakhmono sarah marg wa pah ghaț gảm dar pasay

Death with bloody wounds was swiftly following you.

Images in poem Akhri Sughat

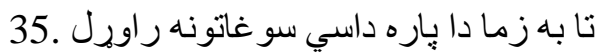

Tả ba zama da parah dasy sughatuna rawral

You were bringing such kind of gifts for me

جه مي وره غوندي دنيا وه يه رنكينه مدام

Che me wara ghunday dunya wả pah ranginah mudảm

Which have made my little world colorful

36. 3ي دا كلاب د بنسكلو بنكلو، سرو كلونو بِه شان

Chy da gulab da Šhkulo Šhkulo, sro gulono pa shản

Like beautiful flowers of a rose."

The lexical phrases "turah shpa" (dark night) in (33), "sro zakhmono" (bloody wounds) in (34), "sughatona" (gifts) in (35) and the phrases "da gulab" (of rose) and "sro gulono pa shản" (like a red roses) in (36) are concrete images which gives pictorial quality to his poems. Metaphors are also used, as is the case with the following lines.

Metaphors in poem Nave

خه ترخي ورخي وب جي ؤ د مري يور در بِ

Tsu tarkhay wratzay wey che wu da marhi por dar pasay

How bitter days were when you had blood on your hands

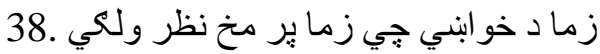

Zama da khwakhay che zama par makh nazar wa lagi

When my mother in law's glance falls on my face

به دي هينداره كي ستا لاس او ستا خنجر و ويني

Puh de hindarah ke sta laas ao sta khanjar wu weni

In this mirror, she sees your hand and your dagger."

Metaphors in poem Akhri Sughat

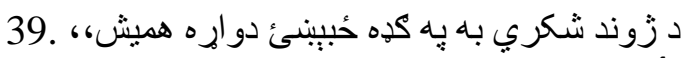

Da zhund shakary bah pah gadah $\hat{\text { weshi dwara }}$

We both will enjoy the sweets of life forever.

40. د اسمان ستركي مو مري كري د دبنمن به ويه وينو

Da asmản stargy mo mare kre da dukhman pa wino

Satiated the eyes of the Sky with blood of enemies." 
The lexical units "tarkhe wratzy" (bitter days) in (37), "zhund shakary" (sweets of life) in (39) and "Da asmán stargy" (eyes of the sky) are conventional and lexicalized metaphors which are used in our everyday language. These conventional metaphors can be explained within the conceptual metaphor perspective as investigated by Sardaraz and Nusrat (2019). The lexical unit at (38) "Puh de hindảra ky" (in this mirror) is a poetic metaphor which compares the face of bride to a mirror. The following lines also reveal poetic figurative language.

41. ككه شهباز د سرو خوكو سر ته و ختو

Lakah shảhbaz da saŗo soko sar tah wu khatale

Like a falcon you dwelled upon the high cold peaks.

42. ديري سيني دي د غلبيل به شان سورى سورى كري

Dere sine dy da ghalbil pah shản soray soray kre

You have made holes in your enemies' chests like a stainer." (Akhri Sughat)

In (41) the speaker compares her brother with a falcon through lexical unit "Lakah shảhbaz" (like a falcon), while in (42) the holes in chests are compared with holes in a stainer through the lexical units "da ghalbil pah shản” (like a stainer).

\section{Language and Verse}

The language that is used in both poems is simple. Both poems are in conversational form. In each poem, there is a speaker, directly addresses an implied listener. Following are the examples in which the speaker (first person) addresses the listener (the second person) directly.

Lines from Nave

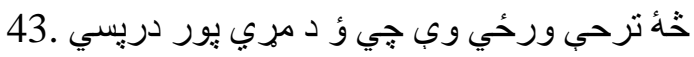

Tsu tarkhe wratzy we chy wa da mari pur dar pasy

How bitter days were when you had blood on your hands!

خُأ بد وختونه وو جي خون دي وو يهـ غاره بابا

Tsu bad wakhtuna wu chy khun dy wu pah ghara baba

$\mathrm{O}$ father! how hard times were, when you had the yoke of murder

تا جي له وينو سره تور لحد ته ولبيرله

Ta chy lah wino sara tor lahad ta wa leżhalah

That you sent to the dark grave stained in blood

هغه خهره به دي وه ستركو ته ولاره بابا

Haghah tsehra bah dy wa stargo tah wolara baba 
O father his face appeared to you all the day

يها زوند كي دومره بد كمانه وب جي خيل لاسونه

Puh zhund ky dumra bad gumana we chy khpal lasona

You became so mistrustful in your life that your hands

درته ملكري د دبنمن بنـار بدل دو إره بابا

Dartah malgari da dukhman khkaredal dwaŗa baba

Appeared both to you as your enemy's friends, O father!

Lines from Akhri Sughat

44. زهٔ جي وره غوندي مانشومه وم شهيده وروره

Zuh chy warah ghundy mashuma wom shahidah wrorah

O my martyr brother! When I was little innocent child

تا به له ما سره كوله خُومره مينه مدام

Tả bah lah mả sarah kawula sumrah mina mudảm

You always loved me a lot

تا بهـ زما د باره داسي سو غاتونه راورل

Ta bah zamả da parah dasy sughatuna rawral

You used to bring for me such gifts

جي مي وره غوندي دنيا وه يِه رنكينه مدام

Che my wara ghundy dunya wah pah ranginah mudảm"

That always made colorful my little world. (Akhri Sughat)

The lines at (43) and (44) are coached in simple language, having everyday linguistic phrases such as "tarkhe wratzy" (bitter days), "bad wakhtuna" (evil times), "tor lahad" (dark grave), "Haghah tsehra" (that face), "badgumana" (mistrustful), in (43) and "shahidah wrorah" (O my martyred brother!), "mina" (love), "sughatunah" (gifts), "wara ghundy dunya" (small world) in (44). The use of common noun in (43) and (44) i.e. 'baba' (father) and 'wrora' (brother) and also the use of $1^{\text {st }}$ and $2^{\text {nd }}$ person pronouns such as 'tả' (you) ' $m a$ ' (I-me) and ' $z a h$ ' (I) makes the language of the poem conversational.

The poet has adopted stanzaic form in both poems i.e. the poem Nave is composed in seven lines stanzas with rhyme scheme of ABCBDB as in (43), while Akhri Sughat is divided into five sections and each section having three quatrains with rhyming as $\mathrm{ABCB}$ as in (44).

\section{Dramatic Elements}

Both the poems of Darwesh has a speaker, a listener, an event/occasion, dramatic action/conflict, interplay between speaker and listener and revelation of the characters. The 
speaker addresses a real or an imagined listener, and speaks to him in simple language, as is the case with following lines.

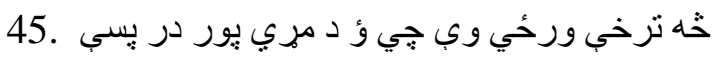

Tsa tarkhe wratzy we chy wa da mari pur dar pasy

How bitter days were when you had blood on your hands!

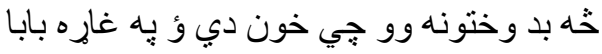

Tsa bad wakhtuna wu chy khun dy wu pah ghara baba

$\mathrm{O}$ father! how hard times were, when you had the yoke of murder

46. خلاصون هره يوه لار جي داسي بنده شوله

Da khlasun harah yawah larah chy dasy bandah shulah

When you didn't find any way to save your life

نو بيا دي زهو و قربانى ته كرم تياره بابا

No biả dy zah wu qurbanxy tah kram tayara baba

Then you have prepared me for the sacrifice

47. دائي به خيال كي دي جى دهُ د خيّل بابا د و ويني

Dai pa khial ky dy chay dah dả khpal baba da winy

This is in his mind that he took his father's blood

زما د شوندو يه صورت كي دــ قيمت اخسن

Zamả da shundo pah surat ky day qimat akhestay

Cost in the form of her as his wife

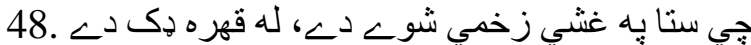

Che sta pah ghashy zakhmi shaway day, la kahra dak day

That who become injured by your arrow, and is filled with anger

لله هغه ماره سره ن.وند كوم، مجبوره يمه

Lah haghah mảrah sara żhwand kawom majbora yama

I am living with that snake, and is helpless.

Lines from Akhri Sughat

إهٔ جي وره غوندي ماشومه وم شهيده وروره .

Zuh chy warah ghundy mashuma wom shahidah wrorah

O my martyr brother! When I was little child

تا به له ما سره كوله خومره مينه مدام

Tả bah lah mả sarah kawula sumrah mina mudảm

You always loved me a lot.

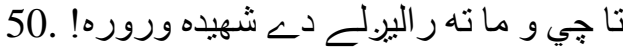

Tả chy wu mả tah rależalay de shahida wrora!

O martyr brother! The gift you sent to me

ير دو إرو ستركو مي قبول د جنتي سوغات د

Par dwaro stargo me qabul da janaty Sughat de 
I happily accept that heavenly gift.

خو تا د وينو نذر انه وركره د قام به نامه .5hah

Kho tả da wino nazranah warkŗa da qảm pa nảmah

For your nation's sake you offered sacrifice of your blood

له شهيدانو سره كر بلي دنيا ته لاري

Lah shahidảno sara gad baly dunia tah laray

And along with martyrs you transcended to another world

52. تر خو مو زوند بِر دنياوي، تر خو مو وس رسيزّي

Thar tso mo zhwand par dunia wy, tar tso mo was rasyzhi

Till my last breath and strength if I have

وفا به كاندو يو له بله سره، يت به كوو

Wafả bah kảndo yo lah balah sarah pat bah kawo

We will be devoted to each other and will abide by honor.

In (45) to (52) the use of $1^{\text {st }}$ and $2^{\text {nd }}$ person pronouns and also the use of common noun 'baba' (father) and 'wrora' (brother) used by speaker shows that there is speaker speaking to listener or it shows an interaction between the speaker and the listener. In (49) (50), the listener is brought back by the speaker through her imagination. The occasion in poem 'Nave' as shown in (45) and (46) is the marriage of the bride, and also the situation that she faces after her marriage with the son of a person who is killed by her father. The occasion/event in poem 'Akhri Sughat' is the death of the speaker's brother, and the conflict in her mind is about her future spouse, which her brother had promised her to arrange for her. The speaker is put in a dramatic situation by the poet and reveals her character and the listener's character gradually not at once in order keep readers in suspense.

In (45), the speaker reveals the character of her father as a murderer who is always afraid from his enemies, as at any point, they might take revenge upon him. The timidity and cruelty of her father is laid bare, who would do anything to save his life. The phrases "tarkhe wratzy", (bitter days) and "bad wakhtuna" (evil times) clearly indicate the psychological conditions of her father. The lines at (47) and (48) reveal the character of speaker who is feeling uneasy at her husband's home because her husband looks down upon her as the daughter of the murderer of his father. Thus, both these examples show the character of the speaker as the victim of the social custom and her husband's thirst for revenge which never let him go to love his wife.

The lines at (50) reveal the character of the listener as a loving brother who would do anything for his sister, and lines at (51) shows him a patriot who would sacrifice his own life 
for defending his country. The phrases "da wino nazranah" (sacrifice of life) and "pat bah kawo" (will abide by honor) in (51) and (52) show the patriotism of both the speaker and her brother. The line at (51) also shows the religious mind of both the speaker and her brother.

\section{Discussion}

The analysis reveals that Darwesh's has the same dramatic feature as are found in Browning poetry. The analysis supports Sessions (1947) regarding her basic elements of Browning's dramatic monologues i.e. speaker, listener, interplay between speaker and listener, occasion/event action, action must be dramatic, revelation of characters. Browning's poems show the presence of speaker, listener, interaction between the characters and their revelation as discussed at (23) to (32). Darwesh's poems exhibits the same features as are evident at (45) to (52). But the listener in poems is not active like in Browning poems, as the listener in Akhri Sughat is the work of imagination of the speaker, as the listener is a dead man. The analysis reveals that the speaker is put in a dramatic situation, having dramatic conflict, either internal as is the case with internal conflict found in My Last Duchess in the mind of the duke regarding his late wife, and in Akhri Sughat in the mind of the speaker regarding her future spouse and her patriotism and that of her brother. Similarly, external conflict can be found in the poetry of both poets, as is the case with external conflict of Andrea del Sarto with his wife Lucrezia and the external conflict of the speaker in the poem Nave with her father and her husband's family. Thus, Darwesh's poems are dramatic monologues if dramatic monologue is defined in broad terms as by (Byron, 2003).

The analysis revealed that both poets are from different eras, cultures, literatures and different languages, but still their poetry have similarities. If Browning uses simple language, having simple dictions, extensive use of pronouns in direct conversational form and negative and interrogative sentences, as is evident in lines at (8) to (16), Darwesh makes use of simple language, having everyday conventional phrases, pronouns and direct speech as is analyzed at (43) and (44). Both the poets also use figurative language, as is evident at (1) to (7) in Browning's poems and (33) to (42) in Darwesh's poems.

The analysis also revealed differences between Browning and Darwesh's dramatic monologues. Both poets have used a conversational form used different numbers of personal pronouns i.e. Browning's poem Andrea del Sarto consists of 2217 words, out of which 135 are pronouns. This shows that he has used extensive use of pronouns. Data analysis reveals that he has used "I" (3.02\%), "me" $(0.9 \%)$, "mine" $(0.2 \%)$, "myself" $(0.13 \%)$, "yours" $(0.05 \%)$, "you" (1.9\%) out of total words. Similarly, My Last Duchess consists of 423 words out of which 31 are pronouns, in which Browning has used "I" (2.6\%), "my" (1\%), "myself" 
$(0.2 \%)$, “mine" $(0.2 \%)$, “we” $(0.4 \%)$, “you” (1.7\%), “yours" $(0.2 \%)$, and “your” $(0.4 \%)$ out of total words. Darwesh "Akhri Sughat" consists of 571 words out of which 34 are pronouns. The percenage of different pronouns is "ن̈" “tả-you” (2.27\%) "ما" "mả-I and me" (0.87\%),

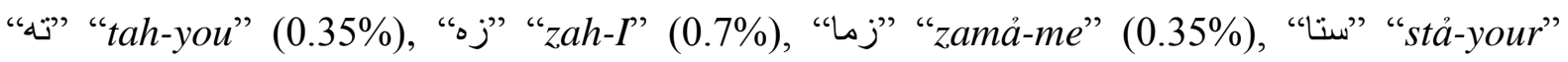
(1.40\%). Nave consists of 423 words, which have 17 pronouns. The percentage of pronouns

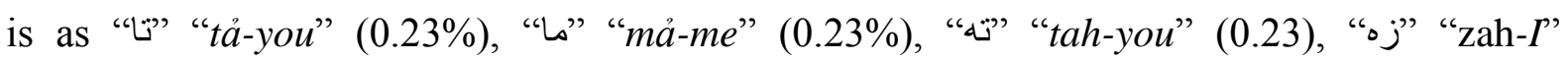

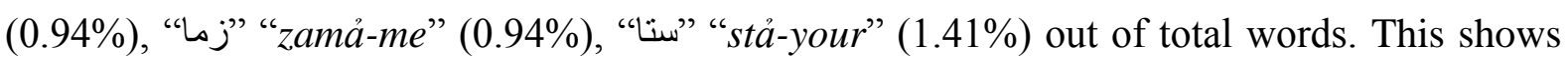
that Browning's style is more conversational than Darwesh. However, in Pashto language, pronouns are often affixed or suffixed to verbs as inflection and therefore, the number of independent pronouns might be less than found in Browning.

Browning has used poetic metaphors in his poetry as is the case with lines at (5) and (6). On close reading of his poems, it was found that Browning has used only three metaphors in both the poems. Darwesh has used both poetic and conventional metaphors (refer to examples at 37 to 40). Darwesh has used fifteen metaphors in both the poems. Both the poets have also used similes, but there is difference in their frequency. Darwesh has used 5 similes in Akhri Sughat, but he has not used any simile in Nave. Browning has used only one simile (refer to 7) in his poem My Last Duchess. This shows that Darwesh poems are more poetic than Browning's poem. Moreover, whereas Browning has used blank verse in his poetry, which is more suitable to dramatic poetry, Darwesh has used stanza form, which is more relevant to lyric poetry. Thus, figurative language and rhyme scheme in Darwesh make his poems more poetic, while, the simple conventional language and blank verse or heroic couplet make Browning's poems more dramatic.

The most important difference in the two writers is the selection of themes. Browning has dealt with the themes of love and marriage, gender discrimination and domestic violence in his poetry (refer to discussion on lines from 17 to 32). Darwesh has used his poems as a tool to castigate the traditional custom of giving one's own daughter in return for reconciliation to the family of person being killed. The speech of the girl is a lyrical protest not only against her father, but it is a protest against the custom of Pashtun society, where female is used sometimes as a property to be given to another either as diyat or ransom to avoid retribution and revenge. Darwesh vehemently reproaches through the female character of Nave (Bride) this custom of Pashtun society. In "Akhri Sughat", Darwesh deals the theme of war and status of women. Though, it clearly shows patriotism, but it also reveals the consistent warfare in Pashtun areas, which has been targeted in the poem. On the other hand, it reflects the status of women in lyrical language and sentimental manner to highlight the 
plight of female in Pashtun society. The tender feelings of having a good match in life are often lost when the elder of the family is killed or martyred in the war. While Browning stands away from religion in his poetry, Darwesh seems to have shown propensity for religious instruction for war, as is evident from the "shahidah wrorah" (O martyred Brother!). In Darwesh selected poems speaker are females, describes situation of females in Pashtun society, while speakers in Browning selected poems are males representing situation of males in domestic life. Browning's monologues studies past in present (as he used historical characters in his monologues), while Darwesh's monologues studies present in the present.

\section{Conclusion}

This paper revealed differences between Browning and Darwesh, which are due to variations in their language, culture, religion, and eras, but the analysis also revealed similarities which may be due to the universal human attributes. Derwesh's poetry shows the dramatic elements as found in Browning's dramatic monologues, but Derwesh's poems are more poetic, while Browning's poems are more dramatic. Browning poems show domestic violence, with Victorian touch for the male dominance, while Darwesh in his poems is the spokesman of the female plight in the male dominated society. Browning sets his poems in the past to speak about the present, but Darwesh speaks about the present in the present setting through his characters. This paper illustrates the presence of dramatic monologues in Pashto literature, and recommends further research into Darwesh's poetry to carry out socio-cultural study of his dramatic monologues.

\section{References}

Bacha, M. S. (2010). A Study of the Comparative Elements in the Poetry of Keats \& Ghani Khan. Language in India 10(11): 185-201.

Bajawrhi, B. (2007, August 27). The subject of Darwesh Durrani's poetry ( دروبش دراني (دشاعرى موضوع). Zoley. Retrieved.from :http://zoley.blogfa.com/post/126?fbclid= IwAR1zQzT02rpJsr4W1RJ4GPKvZaQaim2K3B7v8NfBBiJhRHsdpWxjanyhhIQ

Byron, G. (2003). The Dramatic Monologue. London: Routledge.

Cao, S. \& S. Shi (2011). The Variation Theory of Comparative Literature \& the CrossCivilization Studies. Comparative Literature: East \& West 14(1): 5-26.

Culler, A. D. (1975). Monodrama \& the Dramatic Monologue. Publications of the Modern Language Association of America, 90(3) 366-385.

Curry, S. S. (1908). Browning \& the Dramatic Monologue: Nature and Interpretation of an Overlooked Form of Literature, Expression Company.

Duncan, J. E. (1953). The Intellectual Kinship of John Donne \& Robert Browning. Studies in Philology 50(1): 81-100. 
Ehsan, M. (2016). Historical English poetic comparison with Pakistani poetical forms in Wordsworth \& Shinwari's poetry. Journal of Literature, Languages \& Linguistics 24: $1-12$.

Fox, R. (2011). Robert Browning's necropoetics. Victorian Poetry 49(4): 463-483.

Gardner, K. J. (2006). John Betjeman's Bristol \& Clifton: Echoes of Robert Browning's My Last Duchess. ANQ: A Quarterly Journal of Short Articles, Notes \& Reviews 19(3): 35-38.

Garratt, R. F. (1973). Browning's dramatic monologue: The strategy of the double mask. Victorian Poetry, 11(2): 115-125.

Ghazanfar, A. (2014, February, 3). Rhyme Scheme of Darwesh Durrani (د دروبش دراني قافيب). Taand, Taand Afghanistan.

Gregory, M. V. (2000). Robert Browning \& the lure of the violent lyric voice: Domestic violence \& the dramatic monologue. Victorian Poetry 38(4): 491-510.

Haigwood, L. E. (1986). Gender-To-Gender Anxiety and Influence in Robert Browning's Men \& Women. Victorian Literature and Culture 14: 97-118.

Hamdard, S. M. (2015, July 2). Four advanced poets of 21st century ( ديوويشتمي بيرى خلور مخكبن شاعران). Afghan German Online.

Hodgson, A. (1992). Riding Together: William Morris \& Robert Browning. Journal of the William Morris Society 9(4): 3-7.

Holman, C. H. and W. Harmon (1992). A handbook to literature. Macmillan Publishing Company.

Ingersoll, E. G. (1991). Considerations of Gender in the Dramatic Monologue. The Modern Language Review, 86(3): 545-552.

Iqbal, I. (2008). A technical analysis of Darvaish Durrrani’s Ghazals ( دروبش دراني د غزل كوئى فني جائزه . Pashto 38.

Khalil, H. (2012). Condemnation of war and terror in Pashto Poetry-Post 9/11 scenario. TIGAH: A Journal of Peace and Development, II: 41-65.

Maenhout, F. (2007). Gender Relations in Robert Browningâ€ $\mathrm{TM}_{S}$ Dramatic Monologues. Ghent University.

Mohammad, S. S. (2016). A Comparative study of class-consciousness between Khushhal Khan Khatak and Charles Dickens. European Academic Research IV(4): 3681-3696.

Plamondon (2002). The musical aesthetics of the poetry of Tennyson \& Browning (Robert Browning, Alfred, Lord Tennyson). English Literature. Toronto: University of Toronto (Canada). Ph. D.

Prakash, M. (2017). Robert Browning \& Alfred Lord Tennyson: A comparative study. Pune Research: An International Journal in English 3(6): 1-7.

Remak, H. (1971). Comparative literature: Its definition and function. In N. P. Stallknecht and H. Frenz (eds,). Comparative literature: Method and perspective, (pp 3-57). Carbondale: Southern Illinois Press.

Roche-Jacques, S. J. (2013). Time, space \& action in the dramatic monologue: Men, women \& mice. Sheffield Hallam University.

Salunke, S. (2014). Some dimensions of violence in Robert Browning's My Last Duchess. New Academia III(II): 1-6. 
Sardaraz, K., \& Nusrat, A. (2019). Concept of life \& death in Ghani Khan's poetry: A cognitive semantic approach. FWU Journal of Social Sciences 13(3): 15-19.

Scheinberg, C. (1997). Recasting sympathy \& judgment: Amy Levy, Women Poets, \& the Victorian Dramatic Monologue. Victorian Poetry 35(2): 173-191.

Sessions, I. B. (1947). The dramatic monologue. Publications of the Modern Language Association of America, 62(2): 503-516.

Sharp, W. (1897). Life of Robert Browning. London, Walter Scott, Limited.

Sinfield, A. (1977). Dramatic monologue. Oxfordshire: Taylor \& Francis.

Wellek, R. \& A. Warren (1956). Theory of literature. New York: Harcourt Brace.

Wenger, C. N. (1941). The Masquerade in Browning's Dramatic Monologues. College English 3(3): 225-239. from Asia, Africa and South America, pp. 2, 3.

Zahir, U.A. (2011, December 8). Darwesh Durrani and the Pashtuns' discomfort ( دروبش در انى (او ديبنتنو ناخو الي Retrieved from https://1.khabarial.com/ 